\title{
Developing thermal comfort model through regional budget expenditure analysis towards low energy consumption in public building facility (case object: government building in north and south of Jakarta)
}

\author{
Bayu Andalas ${ }^{1 *}$, Haryoto Kusnoputranto ${ }^{1}$ and Raldi H. Koestoer ${ }^{1}$ \\ ${ }^{1}$ School of Environmental Science, Universitas Indonesia, 10430, Salemba, Indonesia.
}

\begin{abstract}
Building efficiency policy has implemented Indonesia. However, energy consumption in building sector remains significantly increased. Jakarta Government relied on AC in providing a comfortable condition for its service it consumed $57 \%$ of its total energy consumption. Current available energy monitoring method based on the expensive electrical device, so a new method using regional budget expenditure is developed in this research. This study established: Field study (6 buildings), regional budget expenditure analysis (313 buildings) on thermal comfort and building energy in 112 administrative office building equipped with Natural air ventilated (NV) and Air Conditioned (AC) and 224 building occupants/building manager were taking part in this research. Quantitative method used in this research with variables: thermal comfort (Air temperature, Relative humidity, radiant temperature, Air velocity, and personal clothing index) with Fanger's Predicted Mean Vote (PMV) method calculation. Another variable used in this research is government standard for Building Energy Consumption Index (IKE) through regional government budget analysis. During an early stage, the budget analysis shows 6 out of 112 office buildings energy consumption (electricity) categorised as 'extravagant.' Field study higher IKE caused by too cold temperature setting, underperformed Air Conditioning System, building envelope and ventilation or 'inappropriate' building orientation (facing east-west).
\end{abstract}

\section{Introduction}

Building efficiency policy has implemented in many countries, but the energy consumption in the building sector remains significantly increased, residential and commercial building consumed more than $40 \%$ world energy resources and producing more than $30 \%$ Carbon Dioxide Emissions[1]. HVAC (Heating, Ventilation and Air Conditioning) is playing an important role in building energy consumption and directly impacted thermal comfort for building's inhabitant [2]. [3] Thermal comfort as a part of Indoor Environment Quality (IEQ) influence work productivity. In US-based research showed better IEQ is increasing 0,5-5\% productivity equal to US\$ 12 Billion to US\$125 Billion per year in the US industry [4]. Jakarta Provincial Government as a special region in Indonesia pioneered to prioritising

\footnotetext{
${ }^{*}$ Corresponding author: bayu.andalas@ui.ac.id
} 
public service and its civil servant productivity. In fulfilling its commitment, Jakarta Provincial Government is established 313 regional offices in its district (267) and subdistrict (44) to public services, public gathering, and any administrative services. The building IAQ become an important part to make the occupant's comfort [5]. Every district and sub-district offices equipped with AC (Air Conditioner) in its common room and back office room. The problem is raising while the electric consumption year to year shows an uptrend. As an example, Electric Consumption in Kelurahan in Jakarta Year to year electric consumption is showing a higher consumption every year. In this case, the government need to monitor every of its building energy consumption and provide a way to reduce energy consumption. Devices invented by Sharmin et al. [6] has an accurate device monitoring method but has an expensive and relatively difficult to operate. A better solution and human social based approach are needed to solve this condition, one of the solutions is through an analysis through well-established regional budget expenditure systems.

\section{Method}

This research aimed to develop affordable thermal comfort model for environmentally friendly (low energy) public building facility to support sustainable development in a metropolitan city. This research also identifies tradeoff between thermal comfort and energy consumption; identify building occupant's perception to low energy building as a part of human dimension impacting energy consumption to support low energy public building facility to support sustainable development. Data in this study consist of Field study, questionnaire, regional budget expenditure analysis (313 buildings) on thermal comfort and building energy in 112 administrative office building equipped with Natural air ventilated (NV) and Air Conditioned (AC). Three Hundred Thirteen (313) building manager/admin and 224 building occupants consist of Government Official (PNS), Nonpermanent employee and Public who claimed services in the government office building taking part in this qualitative/quantitative research. A depth field study also examined in 6 buildings indicated has the worst energy consumption.

$$
I K E=\frac{\text { electricity usage }(\mathrm{kWh})}{\text { Occupancy rate } \mathrm{x} \text { Building area }}
$$

Determine the IKE level from each building by using several parameters: electricity usage $(\mathrm{kWh})$, Building Area $(\mathrm{m} 2)$ and Building occupancy (\%) with equation [7] shown above. This research aimed to develop affordable thermal comfort model for environmental friendly (low energy) public building facility but has a high productivity employee with high public service index (IPM) to support sustainable development in a metropolitan city. This research also identifies tradeoff between thermal comfort and energy consumption; identify building occupant's perception to low energy building as a part of human dimension impacting energy consumption; Analysis of correlation between thermal comfort and public service index (IPM) and creating a thermal comfort model to support low energy public building facility to support sustainable development.

Mix method used in this research (Quantitative and Qualitative) with variables: Energy Consumption (parameter: IKE/Energy consumption index), thermal comfort (Air temperature, Relative humidity, radiant temperature, Air velocity, and personal clothing index) with calculation Fanger's [8] and developed by Karyono [9] Predicted Mean Vote (PMV) method. The shortlisted office will be performed a depth qualitative interview to identify factors influencing energy consumptions, thermal comfort and effort to reduce 
energy consumption through a model building. Data collection procedure is using: government budget expenditure monitoring and evaluation report system (http://monev.bapedadki.net), this system used by 313 building manager to report every expenditure related to any budget expenditure in every office. In this research case, only electricity expenditure data reported by the building manager collected. The building manager is not informed about the objective of this research — the expenditure on electricity based on accurate transaction recorded by the bank. The data collected from the year 2016-2018 (ongoing) is showed in ( $\mathrm{Rp}$.) then converted to ( $\mathrm{kWh} / \mathrm{month}$ or /year) also considering electric bill rate applied during the data collected. (Rp. 1.364,86/kWh in 2016, Rp. 1467,28/ kWh in 2017-2018) Moreover, also considering the $10 \%$ government tax. The study area located in the Northern and Southern part of Jakarta, the capital city of Indonesia.

The area of every building is examined using data from building a database (http://smartcity.jakarta.go.id) providing a total of the area of every building object and employee occupancy rate in every office data (http://kepegawaian.jakarta.go.id) to accurately measure every single government office employment data in every office. Using this method every office's IKE can be measured accurately. Shortlisted building with high IKE index will be conducted a depth field survey to examine factors causing energy consumptions. The various approach is conducted to measure thermal comfort (direct reading and questionnaire). Direct reading collected by Laboratory of Jakarta's Company Hygiene and Work Safety Agency (HIPERKES) collected data using 3M $\mathrm{M}^{\mathrm{TM}}$ QUESTemp ${ }^{\mathrm{TM}}$ 36 Heat Stress Monitor Data logging Kit. With parameters: Air temperature, Relative humidity, radiant temperature, Air velocity, and personal clothing index. Employee's (uniform clo value is 0.5 ), measurement device are operated by national certified operator. Thermal comfort data is analyzed with a standard and method using: SNI national standard a national standard is SNI 16-7061-2004. 3(three) times in a day between 08:00 WIB, 11:00 WIB and 16:00 WIB The variety of data is analyzed and counted using PMV method by [8] in CBE Thermal Comfort Tool (http://comfort.cbe.berkeley.edu). To examine occupant's thermal comfort, A questionnaire is deployed to understand every individual response and accepting thermal conditions.

\section{Discussion}

Two (2) factors influence energy consumption consist of internal loading (occupant, lighting and thermal) and external loading (sun radiation/climate/geographical condition). [11], in term of geographical condition, the northern part of Jakarta is close to the sea rather than the southern part of Jakarta [12], it means the external loading in the northern part should be higher, and theoretically consume more energy rather than the southern part. The result showed a different way, the highest consumer of the energy mostly came from the southern part. In table. 1 below shown 3 top public building facility which consumes the most energy and the following table shown the thermal comfort analysis in the highest energy consuming building.

Table 1. Top 3 public building facilities in South Jakarta consumed most energy.

\begin{tabular}{|c|c|c|c|c|c|c|c|c|}
\hline Part & $\begin{array}{l}\text { Sub } \\
\text { District }\end{array}$ & $\begin{array}{l}\text { Land } \\
\text { Area } \\
\left(\mathbf{M}^{2}\right)\end{array}$ & $\begin{array}{l}\text { Buildi } \\
\text { ng } \\
\text { Area } \\
\left(\mathbf{M}^{2}\right)\end{array}$ & $\begin{array}{l}\text { Effective } \\
\text { Building } \\
\text { Area } \\
\left(\mathbf{M}^{2}\right)\end{array}$ & $\begin{array}{l}\text { Oc } \\
\text { c }\end{array}$ & $\begin{array}{l}\text { Electricity } \\
\text { Rate } \\
\text { Payment } \\
2017 \text { (Rp.) }\end{array}$ & $\begin{array}{l}\text { Energy } \\
\text { Consum } \\
\text { ption } \\
\text { (kWh/ } \\
\text { year) }\end{array}$ & IKE/ Year \\
\hline South & $\begin{array}{l}\text { Menteng } \\
\text { Atas }\end{array}$ & 1400 & 200 & 140 & 18 & $\begin{array}{l}132.681 .74 \\
8\end{array}$ & 90.427 & 922,7246 \\
\hline
\end{tabular}




\begin{tabular}{|c|c|c|c|c|c|c|c|c|}
\hline Part & $\begin{array}{l}\text { Sub } \\
\text { District }\end{array}$ & $\begin{array}{l}\text { Land } \\
\text { Area } \\
\left(\mathbf{M}^{2}\right)\end{array}$ & $\begin{array}{l}\text { Buildi } \\
\text { ng } \\
\text { Area } \\
\left(\mathbf{M}^{2}\right)\end{array}$ & $\begin{array}{l}\text { Effective } \\
\text { Building } \\
\text { Area } \\
\left(\mathbf{M}^{2}\right)\end{array}$ & $\begin{array}{l}\text { Oc } \\
\text { c }\end{array}$ & $\begin{array}{l}\text { Electricity } \\
\text { Rate } \\
\text { Payment } \\
2017 \text { (Rp.) }\end{array}$ & $\begin{array}{l}\text { Energy } \\
\text { Consum } \\
\text { ption } \\
\text { (kWh/ } \\
\text { year) }\end{array}$ & IKE/ Year \\
\hline South & $\begin{array}{l}\text { Cipete } \\
\text { Utara }\end{array}$ & 4860 & 259 & 181,3 & 17 & $\begin{array}{l}153.622 .03 \\
0\end{array}$ & 104.699 & 824,9824 \\
\hline South & Bintaro & 1195 & 234 & 163,8 & 16 & $\begin{array}{l}114.345 .59 \\
0\end{array}$ & 77.930 & 679,6643 \\
\hline
\end{tabular}

\begin{tabular}{lccccccc} 
Room Name & $\begin{array}{l}\text { Temp } \\
\left({ }^{\circ} \mathbf{C}\right)\end{array}$ & $\begin{array}{l}\text { RH } \\
(\mathbf{\%})\end{array}$ & $\begin{array}{l}\text { MRT } \\
\left({ }^{\circ} \mathbf{C}\right)\end{array}$ & $\begin{array}{l}\text { Air } \\
\text { Velocit } \\
\mathbf{y}(\mathbf{m} / \mathbf{s})\end{array}$ & clo & PMV & Result \\
\hline $\begin{array}{l}\text { Public Service } \\
\text { Room }\end{array}$ & 23,3 & 66 & 24 & 0,23 & 0,5 & $-0,81$ & \\
$\begin{array}{l}\text { Administrative } \\
\text { Service }\end{array}$ & 21,9 & 65 & 23 & 0,11 & 0,5 & $-1,53$ & $\begin{array}{c}\text { Too Cold / Does } \\
\text { Pemply with }\end{array}$ \\
Staff Room & 21,3 & 60 & 22 & 0,17 & 0,5 & $-1,35$ & $\begin{array}{c}\text { 2012/Permenkes 48 } \\
\text { 2016/ASHRAE } \\
\text { Standard 55-2017 }\end{array}$ \\
Operator Room & 22,6 & 67 & 22 & 0,23 & 0,5 & $-1,22$ & Stand \\
\hline
\end{tabular}

Kelurahan Menteng Atas which located in a dense urban environment consumes the highest energy with IKE level per year reaching 922,724 kWh/m2/year. Far above the standard $340 \mathrm{kWh} / \mathrm{m} 2 /$ year $\pm 5 \%$. A researcher conducts the field study, thermal comfort analysis and examines factors influencing energy consumption. The high energy consumption is mainly caused by the building condition itself which oriented to East-West rather than avoiding sun North-South orientation, this condition causing a heavy external factor condition [12] like solar radiation. These conditions are forcing the building manager to install more $\mathrm{AC}$ unit to reduce the heat to achieve the thermal comfort condition. Underperformed building envelope can also be related to this condition. Thermal comfort analysis indicates the room is too cold or do not comply with any regulation such as Pergub 38 2012/ Permenkes 482016 or ASHRAE Standard. 55-2018, this condition is forcing $\mathrm{AC}$ device to consume more energy.

Interestingly environment quality questionnaire from the public indicates $82 \%$ is satisfied with the condition. Some are happy with a room with the cold condition, most of the individual says they do not have any AC device in their home, so they were happy to be here. Based on Pemprov DKI (2017-2018) IPM index analysis, public service in southern Jakarta (2017) have the highest point: 3,20 . One of the scorings is an environmental quality; it indicates how this condition contributes to energy consumption. Researcher examines thermal comfort also can be examined through budget analysis.

In table. 2 below shown 3 top public building facility which consumes the most energy in the Northern part of Jakarta and also shown the thermal comfort analysis in the highest energy consuming building in the northern part of Jakarta based on field research: 
Table 2. Top 3 Public Building Facilities in North Jakarta consumed most energy

\begin{tabular}{|c|c|c|c|c|c|c|c|c|}
\hline Part & $\begin{array}{c}\text { Sub } \\
\text { District }\end{array}$ & $\begin{array}{l}\text { Land } \\
\text { Area } \\
\left(\mathbf{M}^{2}\right)\end{array}$ & $\begin{array}{c}\text { Buildi } \\
\text { ng } \\
\text { Area } \\
\left(\mathbf{M}^{2}\right)\end{array}$ & $\begin{array}{c}\text { Effective } \\
\text { Building } \\
\text { Area } \\
\left(\mathbf{M}^{2}\right)\end{array}$ & Occ & $\begin{array}{l}\text { Electricity } \\
\text { Rate } \\
\text { Payment } \\
2017 \text { (Rp.) }\end{array}$ & $\begin{array}{c}\text { Energy } \\
\text { Consump } \\
\text { tion } \\
(\mathbf{k W h})\end{array}$ & $\begin{array}{l}\text { IKE/ } \\
\text { Year }\end{array}$ \\
\hline North & $\begin{array}{l}\text { Sunter } \\
\text { Agung }\end{array}$ & 1961 & 756 & 529,2 & 19 & 155.325 .878 & 105.860 & $\begin{array}{l}285,767 \\
6\end{array}$ \\
\hline North & $\begin{array}{l}\text { Kamal } \\
\text { Muara }\end{array}$ & 2800 & 435 & 304,5 & 17 & 80.360 .333 & 54.768 & $\begin{array}{l}256,946 \\
9\end{array}$ \\
\hline North & Papanggo & 3500 & 774 & 541,8 & 18 & 115.061 .793 & 78.418 & $\begin{array}{l}206,766 \\
9\end{array}$ \\
\hline
\end{tabular}

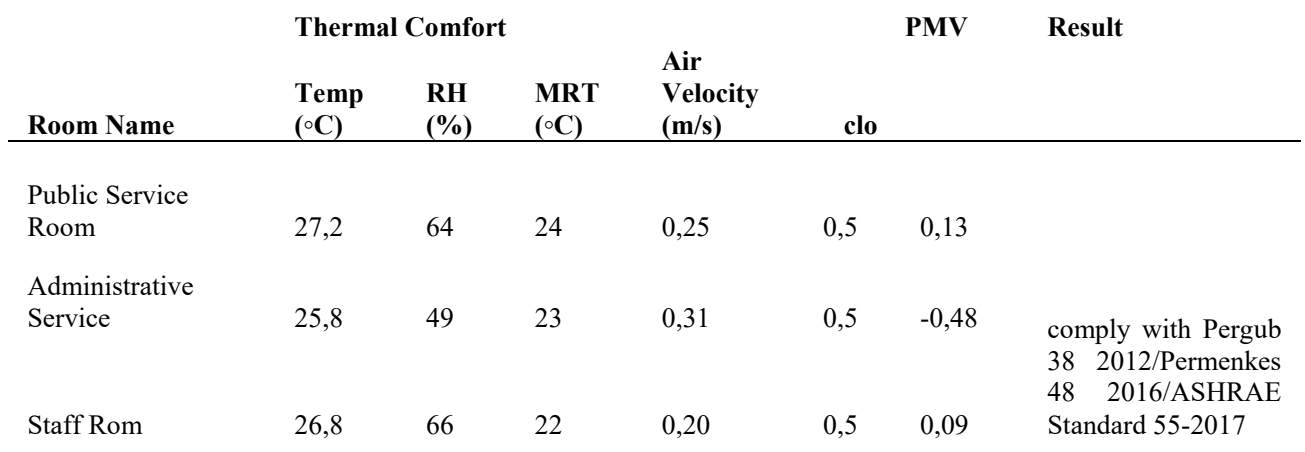

$\begin{array}{lllllll}\text { Operator Room } & 25,3 & 47 & 22 & 0,22 & 0,5 & -0,40\end{array}$

Kelurahan Sunter Agung which located 2.93 KM from the seashore placed in the middle of the housing complex with a majority has good income and better quality of life compared to another region. This building consumes the highest energy. IKE level per year in Northern Part of Jakarta. IKE Index reaching $285,7 \mathrm{kWh} / \mathrm{m} 2 /$ year but still well performed rather than Kelurahan Menteng Atas in Southern Jakarta with 922,724 $\mathrm{kWh} / \mathrm{m} 2 /$ year. A researcher conducts the field study, thermal comfort analysis and examines factors influencing energy consumption. The building orientation is performed good enough by facing North-South. Based on an interview with the building manager, the high energy consumption caused by the usage of the office itself, many events were conducted in this office such as PKK (program at the village level to educate women on various aspects of family welfare), daily event and so on. Remembering this sub-district is prone to flooding disaster. These conditions are forcing the building manager to install more $\mathrm{AC}$ unit to reduce the heat to achieve the thermal comfort condition.

Thermal comfort analysis in Kelurahan Sunter Jaya indicates the room complies with any regulation such as Pergub 38 2012/ Permenkes 482016 or ASHRAE Standard 552018 , this condition has an optimum energy consumption. The quality questionnaire from the public indicates $73 \%$ is satisfied with the condition. Some are happy with a room Based on Pemprov DKI (2017-2018). Researcher examines thermal comfort also can be examined through budget analysis, for example, the budget for AC service history, Type of compressor used, the capacity of the compressor and so on. The result shows many aspects were impacted to thermal comfort and do not always related to energy consumption. From 
the field survey, we understand many social aspects also play an important role in energy consumption. Future study in factors influencing energy consumption by internal loadings such as building envelope or passive ventilation probably will lead to more discussion and field of research in Sustainable Development. In this energy consumption research through budget analysis research, we can see an emerging potential how budget expenditure analysis can be used to monitor a physical mechanism. In the future, a detailed level of budgetary analysis such as component and volume analysis could be expanded to conduct another research and analysis to solve problems in many aspects; this research also can be expanded by adding Life Cycle Analysis to each component examined. The cost of this method to monitor energy consumption is cheaper compared to another method. Pemprov DKI Jakarta as a local government has implemented e-budgeting since 2014 and implementing this method in a more advanced way. Future open data and public access to this monitoring system in this research will open more research chance and public transparency.

\section{Acknowledgement}

This research / article's publication is supported by the United States Agency for International Development (USAID) through the Sustainable Higher Education Research Alliance (SHERA) Program for Universitas Indonesia's Scientific Modeling, Application, Research and Training for City-centered Innovation and Technology (SMART CITY) Project, Grant \#AID-497-A-1600004, Sub Grant \#IIE-00000078-UI-1.

\section{References}

1. S. Hadi, E. Annisa, E3S Web of Conferences 31, 01008 (2018)

2. L.-P. Lombard, J. Ortiz, C. Pout, Energy and Buildings (2007)

3. M. Esfandiari, S.M. Zaid, M.A. Ismail, A. Aflaki, Influence of indoor environmental quality on work productivity in a green office building: A review. Chemical Engineering Transactions (2017)

4. L. Li, P. Wargocki, Z. Lian, Energy and Buildings (2011)

5. A. Feige, H. Wallbaum, Journal of Corporate Real Estate 15, 1, 7-34 (2011)

6. T. Sharmin, X. Li, Sustainable Cities and Society (2017)

7. J. Untoro, H. Gusmedi, N. Purwasih, Audit Energi dan Analisis Penghematan Konsumsi Energi pada Sistem Peralatan Listrik di Gedung Pelayanan Unila (2014)

8. P.O. Fanger, Thermal Comfort (Krieger Publishing Company, Malabar, Florida, 1982)

9. T.H. Karyono, Report on thermal comfort and building energy studies in Jakarta Indonesia (Building and Environment, 2000)

10. U. Gazder, E3S Web Conf. World Renewable Energy Congress-17 (2017)

11. Nugroho, et al., Audit Energi Gedung Dirjen LPE (PPE-ITB, 2007)

12. G. Golany, Atmospheric Environment 30, 3, 455-465 (1996) 